\title{
RISALAH|
}

DOI: $10.24014 /$ jdr.v30i1/7003

\section{KOMUNIKASI KONSELING DALAM PENYELESAIAN TUGAS AKHIR}

\author{
Ulin Nihayah \\ Fakultas Dakwah dan Komunikasi UIN Walisongo Semarang \\ Email: ulinnihayah@walisongo.ac.id
}

\section{Kata kunci}

Konseling, Komunikasi

konseling, konselor

\begin{abstract}
Abstrak
Artikel ini membahas komunikasi konseling yang ditemukan di Universitas Islam Negeri Walisongo Semarang. Mahasiswa dalam menyelesaikan tugas akhir dihadapkan berbagai permasalahan baik faktor internal maupun eksternal. Permasalahan ini membutuhkan komunikasi konseling untuk mengidentifikasi permasalahan mahasiswa secara preventif. Teknik komunikasi konseling dilakukan melalui komunikasi verbal, komunikasi vokal, dan komunikasi tubuh. Penelitian ini menggunakan pendekatan kualitatif deskriptif. Teknik pengumpulan data dilakukan dengan cara indepth interview, observasi dan dokumentasi. Hasil penelitian mengungkapkan komunikasi konseling yang dilakukan dosen wali tidak bisa maksimal dilakukan pada komunikasi verbal karena kurangnya informasi pada diri mahasiswa yang jarang melakukan interaksi dengan dosen.
\end{abstract}

Keywords
counseling
communication,
counseling,
counselor

\section{Pendahuluan}

Memasuki era milenial 4.0, komunikasi merupakan sebuah hal yang tidak bisa dihindari. Tak jarang komunikasi yang dilakukan tidak mengenal waktu dan tempat, dimanapun dan kapanpun. Komunikasi dianggap sebagai jalan penghubung dari satu individu, kepada individu lainnya, individu dengan organisasi, bahkan antara organisasi. Salah satu pengguna komunikasi ini adalah perguruan tinggi yang merupakan pengguna komunikasi yang bersifat interaksi dan interkoneksi, antara dosen dan mahasiswa beserta semua elemen pelayanan yang ada didalamnya. 
Menurut penelitian terkait komunikasi yang dilakukan oleh Dr. Everett Kleinjan dari East West Center Hawaii, dalam Cangara (2010) Orang yang tidak pernah berkomunikasi dengan orang lain niscaya akan terisolir dari masyarakatnya. (Cangara, 2010). Hal ini juga dapat diartikan bahwa penggunaan komunikasi digunakan sebagai dasar dalam berbuat, bertingkah laku, serta mengembangkan diri, sehingga komunikasi dianggap sebagai kebutuhan manusia, layaknya manusia saat bernafas. Jika ingin hidup, terutama bersosialisasi sangat memerlukan komunikasi dalam kehidupannya.

Pada penelitian yang dilakukan Salman dkk (2016) menyebutkan bahwa komunikasi konseling bisa meningkatkan kualitas hidup remaja, terutama pada remaja yang duduk pada bangku sekolah menengah atas. (Salman dkk, 2016). Hal ini menunjukkan komunikasi konseling dapat membuat dinamika hubungan konselor dan konseling dalam ranah pendidikan di sekolah untuk mengembangkan kompetensi pada konseling.

Lebih dari hubungan penyampai pesan atau penerima pesan, berkomunikasi yang dapat diterima baik adalah komunikasi efektif. Komunikasi yang efektif adalah komunikasi yang hasilnya sesuai dengan harapan para pesertanya (orang-orang yang sedang berkomunikasi). Oleh karena itu, untuk mencapai suatu komunikasi yang efektif di dalam organisasi maupun interpersonal, terdapat lima komponen dalam komunikasi yaitu: komunikator, pesan, media, komunikan dan efek. Jadi, komunikasi yang efektif adalah apabila proses komunikasi berjalan baik dengan melibatkan kelima komponen di atas. Namun, sayangnya terkadang proses komunikasi berjalan tidak efektif akibat adanya gangguan pada salah satu komponen.

Suatu hubungan dalam komunikasi dibangun ketika seseorang mengenal orang yang lain melalui interaksi yang dilakukan secara personal. Pada komunikasi tatap muka, bentuk komunikasi yang terdapat pada perguruan tinggi contohnya ialah komunikasi antara dosen dan mahasiswa. Interaksi ini bisa dilakukan pada saat perkuliahan berlangsung atau bisa melalui konsultasi mahasiswa dengan dosen penasehat akademik atau biasa disebut dengan dosen wali.

Komunikasi yang efektif pada perguruan tinggi juga diyakini dapat meningkatkan hasil belajar mahasiswa. (Saputro, 2017). Komunikasi efektif ini dilakukan dalam rangka proses belajar mengajar pada perguruan tinggi. Selain itu, dalam psikologis dijelaskan bahwa konsultasi yang dilakukan mahasiswa tidak bisa berjalan lancar dan efektif apabila tidak ada komunikasi yang baik dari dosen sebagai konselor di perguruan tinggi. Sebagai seorang konselor akademik, dosen mempunyai tugas dalam rangka bimbingan konseling akademik pada perguruan tinggi untuk membantu kesulitan mahasiswa dalam kegiatan belajar serta kegiatan lainnya. Adanya komunikasi dosen dengan mahasiswa diharapkan lebih mudah mengidentifikasi masalah yang dialami mahasiswa terutama yang berhubungan dengan akademik, sehingga bisa menangani dengan preventif dibandingkan secara kuratif.

\section{Metode}

Penelitian kualitatif ini menggunakan analisis deskriptif terhadap faktor yang mendorong dan menjadi penghambat dari penyelesaian tugas akhir skripsi mahasiswa serta peran dosen wali dalam rangka penyelesaian tugas akhir skripsi mahasiswa. Data utama dalam penelitian ini diperoleh melalui materi perwalian yang diberikan dan bentuk layanan 
bimbingan dan konseling. Data dikumpulkan melalui observasi dengan mengamati berbagai aktivitas pelaksanaan perwalian yang dilakukan baik secara langsung maupun tidak langsung, wawancara mendalam (in depth interview) kepada beberapa informan yang memang mempunyai peranan penting, diantaranya dosen wali, mahasiswa dengan permasalahan tertentu dan pihak akademik sebagai penyedia layanan. Data dokumentasi terkait dengan layanan penyelesaian tugas akhir skripsi mahasiswa yaitu buku monitoring perwalian maupun arsip, surat, dan administrasi lain yang terkait.

\section{Hasil dan Pembahasan}

\section{Landasan Teori}

Konseling merupakan sebuah kata yang digunakan oleh sejumlah ahli tertentu untuk mendeskripsikan tentang hal-hal yang mereka lakukan. Konseling yang dilakukan bisa diartikan sebuah aktivitas yang mengarahkan dan saling tukar pendapat antara konselor dan konseling. H.B Inglish \& English (1998) mengemukakan bahwa konseling:"..a relationship in which one person endeavors to help another to understand and solve his adjustment problems". (Effendi, 2016). Pengertian ini mengacu pada keahlian konselor sebagai seorang yang memiliki kualifikasi dan pengalaman serta latihan yang memadai, membantu yang bermasalah tersebut hingga persoalan terselesaikan dan satu individu mempunyai permasalahan tidak bisa memecahkan masalahnya sendiri.

Definisi konseling yang lain juga disebutkan oleh Hahn (1955) dikutip dari Effendi, yang menyebutkan bahwa:"... a process which takes place in a one-to-one relationship between an individual troubled by problem which he can not cope alone, a professional worker training an experience have qualified him, to help others reach solution to various types of personal difficulties (Effendi, 2016) . Konsep konseling yang disebutkan oleh Hahn menunjukkan bahwa konseling mempunyai komponen:

1. Suatu proses, maksudnya konseling berjalan dari waktu ke waktu, tahap satu tahap selanjutnya

2. Merupakan hubungan yang membantu (relationship) antara seseorang yang memiliki kesulitan (klien) yang tidak mampu memecahkan sendiri, dengan seseorang yang profesional (konselor) yang terlatih, berpengalaman, mempunyai kualifikasi yang memadai

3. Tujuan konseling adalah terpecahkannya kesulitan yang dialami oleh klien.

Selain itu, Harold Pepinsky \& Pauline P (1994) menyebutkan bahwa konseling juga merupakan proses hubungan antara satu orang dengan orang lain. Seseorang yang memiliki masalah dan tidak mampu mengatasi masalahnya sendiri adalah klien, sedangkan orang yang profesional, terlatih dan berpengalaman serta mempunyai kualitas dalam membantu orang lain disebut konselor. Disamping itu, dalam proses konseling konselor harus mampu memberikan fasilitas yang memadai pada diri klien agar mampu mengubah tingkah laku mereka.

Bimo Walgito (2010) menyebutkan bahwa konseling merupakan bantuan yang diberikan kepada individu untuk menyeselesaikan masalah kehidupan dengan wawancara dan cara yang sesuai dengan kehidupan kesejahteraan individunya. (Walgito, 2010). Carl Rogers 
dalam Latipun (2011) menyebutkan bahwa konseling merupakan hubungan terapi dengan klien yang bertujuan untuk melakukan perubahan self (diri) pada pihak klien. (Latipun, 2011)

Dari beberapa pengertian konseling di atas dapat disebutkan bahwa konseling merupakan bantuan yang diberikan oleh seorang individu yang merupakan ahli dalam bidang konseling, untuk membantu klien yang mempunyai permasalahan agar mampu mengubah perilaku mereka. Konseling pada mahasiswa merupakan usaha untuk membantu mahasiswa mengembangkan dirinya dan mengatasi problem - problem akademik, problem sosial, serta problem pribadi yang berpengaruh terhadap perkembangan akademik mereka. Konseling mahasiswa ini meliputi bimbingan akademik yang diberikan oleh dosen - dosen pembimbing akademik pada tingkat jurusan / program.

Konseling yang dilakukan pada perguruan tinggi biasanya berbentuk konsultasi. Konsultasi maksudnya suatu layanan yang membantu siswa / mahasiswa dan / atau pihak lain dalam memperoleh wawasan, pemahaman, serta cara-cara yang perlu dilaksanakan dalam menangani kondisi dan/atau masalah peserta didik. (Sukitman, 2015). Lebih lanjut, beberapa fungsi layanan bimbingan konseling dijelaskan sebagai berikut:

a. Pencegahan (Preventif). Maksudnya adalah layanan bimbingan dapat berfungsi sebagai pencegahan. Artinya, hal ini merupakan usaha pencegahan terhadap timbulnya masalah.

b. Fungsi Pemahaman. Fungsi pemahaman yang dimaksud yaitu fungsi bimbingan dan konseling yang akan menghasilkan pemahaman tentang sesuatu oleh pihak-pihak tertentu, sesuai dengan keperluan pengembangan siswa.

c. Fungsi Perbaikan. Pada fungsi ini ditandai saat fungsi pencegahan dan pemahaman telah dilakukan, namun mungkin saja klien masih menghadapi masalah-masalah tertentu. Disinilah fungsi perbaikan itu berperan, yaitu fungsi bimbingan dan konseling yang akan menghasilkan terpecahkannya atau teratasinya berbagai permasalahan yang dialami klien.

d. Fungsi Pemeliharaan dan Pengembangan. Fungsi ini berarti bahwa layanan bimbingan dan konseling yang diberikan dapat membantu para siswa dalam memelihara dan mengembangkan keseluruhan pribadinya secara mantap, terarah, dan berkelanjutan. (Sukardi, 2008)

Pada hubungan konseling, ketulusan, kejujuran, saling menghargai dan keutuhan konselor dan konseli amat penting. Hubungan konseling terjadi atas persetujuan bersama, disertai kerjasama, dan konselor harus dapat menunjukkan sebagai pribadi yang mudah didekati, mudah menerima orang lain, hangat, menampilkan keaslian diri dan dapat dipercaya. Hubungan konseling pada prinsipnya ditekankan bagaimana konselor mampu mengembangkan hubungan konseling yang ditandai keakraban, keharmonisan, kesesuaian, kecocokkan, dan saling tarik menarik (terbentuk rapport) melalui komunikasi.

Secara teoritis, Bernard Berelson dan Gary A. Steiner menyatakan komunikasi didefinisikan sebagai transmisi informasi, gagasan, emosi, keterampilan, dan sebagainya dengan menggunakan simbol-simbol, kata-kata, gambar, figur, grafik, dan sebagainya (Mulyana, 2013). Komunikasi merupakan suatu proses yang membuat sesuatu dari yang semula yang dimiliki oleh seseorang (monopoli seseorang) menjadi dimiliki dua orang atau lebih. Selain itu Brandlun menyebutkan bahwa komunikasi timbul didorong oleh kebutuhan- 
kebutuhan untuk mengurangi rasa ketidakpastian, bertindak secara efektif, mempertahankan atau memperkuat ego (Vardiansyah, 2008).

Terry dan Franklin menyebutkan bahwa komunikasi merupakan seni mengembangkan dan mendapatkan pengertian diantara orang-orang. Komunikasi juga disebut proses penukaran informasi dan perasaan diantara dua orang atau lebih dan penting bagi manajemen yang efektif (Moekijat, 2011). Pendapat komunikasi yang lain oleh Gerald R.Miller menyebutkan komunikasi terjadi ketika suatu sumber menyampaikan suatu pesan suatu penerima dengan niat yang disadari untuk mempengaruhi perilaku penerima. (Mulyana, 2013)

Jika dilihat dalam komunikasi yang dilakukan dari komunikator ke komunikan terdapat ketrampilan komunikasi melalui teknik komunikasi. Adapun teknik ini: (1) Komunikasi informatif (informative communication), (2) Komunikasi persuasif (persuasive communication), (3) Komunikasi pervasif (pervasive communication), (4) Komunikasi koersif (coersive communication), (5) Komunikasi instruktif (instructive communication), dan (6) Hubungan manusiawi (human relations) (Effendy, 2008). Beberapa teknik komunikasi diatas memilki beberapa tujuan atau fungsi sebagaimana dijelaskan Onong Uchyana Effendy, yaitu untuk menginformasikan (to inform), mendidik (to educate), menghibur (to entertain) dan mempengaruhi (to influence). (Effendy, 2008). Secara umum, bentuk-bentuk komunikasi dibagi atas beberapa bentuk, diantaranya:

a. Komunikasi Intrapersonal: komunikasi dengan diri sendiri. Hal ini menyangkut proses disaat diri menerima stimulus dari lingkungan untuk kemudian melakukan proses internalisasi. Hal ini sering dijelaskan dengan proses ketika seseorang melakukan proses persepsi, yaitu ketika seseorang menginterpretasikan dan memberikan makna pada stimulus atau objek yang diterima panca inderanya. Adapun fungsi dari komunikasi intrapersonal diantaranya:

1) Untuk mengembangkan kreatifitas imajinasi, memahami dan mengendalikan diri, serta meningkatkan kematanan berpikir sebelum mengambil keputusan.

2) Komunikasi ini akan membantu seseorang atau individu agar tetap sadar akan kejadian sekitarnya.

b. Komunikasi Interpersonal (komunikasi antar pribadi), dapat diartikan sebagai proses pertukaran makna orang- orang yang saling berkomunikasi. Komunikasi ini dilakukan oleh dua orang atau lebih dan terjadi kontak langsung dalam bentuk percakapan.

c. Komunikasi Kelompok yaitu interaksi tatap muka antara tiga orang atau lebih dengan tujuan yang telah diketahui, seperti berbagi informasi, pemecahan masalah yang mana anggota- anggotanya dapat mengingat karakteristik pribadi anggota yang lain secara tepat.

d. Komunikasi Organisasi merupakan komunikasi antar manusia yang terjadi dalam konteks organisasi. Dari pengertian tersebut, maka kita dapat memahami bahwasanya komunikasi organisasi adalah proses komunikasi yang berlangsung secara formal maupun non formal dalam sebuah sistem yang disebut organisasi.

e. Komunikasi Massa yaitu organisasi media memproduksi dan menyebarkan pesan kepada publik secara luas. Di sisi lain, komunikasi massa juga diartikan sebagai proses komunikasi dimana pesan dari media dicari, digunakan dan dikonsumsi oleh audiens. Dari batasan singkat tersebut, kita dapat melihat bahwasanya karakteristik utama komunikasi massa adalah adanya media massa sebagai alat dalam penyebaran pesannya. 
Beberapa bentuk pengertian komunikasi di atas dapat disimpulkan bahwa komunikasi merupakan sebuah penyampaian dan pemindahan informasi dari komunikator kepada komunikan melalui tindakan non verbal dan verbal untuk mendapatkan umpan balik sehingga terjadi pemahaman informasi antara komunikator dan komunikan.

Jadi komunikasi konseling merupakan suatu proses pemindahan dan penyampaian informasi, pemikiran, sikap (non verbal) antara konselor kepada klien (konseli) yang terjadi pada konteks tertentu menuai pengaruh tertentu dan ada kesan untuk melakukan umpan balik sehingga dapat meningkatkan pemahaman informasi diantara kedua belah pihak.

Bentuk implementasi bimbingan dan konseling juga dapat diimplementasi dalam firman Allah dalam Al-Qur'an Surat Nahl 125:

Artinya: Serulah (manusia) kepada jalan Tuhan-mu dengan hikmah dan pelajaran yang baik dan bantahlah mereka dengan cara yang baik. Sesungguhnya Tuhanmu Dialah yang lebih mengetahui tentang siapa yang tersesat dari jalan-Nya dan Dialah yang lebih mengetahui orang-orang yang mendapat petunjuk.

Inti dari ayat diatas dapat diidentifikasikan bahwa ayat tersebut merupakan internalisasi dari beberapa teori yang ada dalam bimbingan dan konseling, di antaranya:

a. Teori Al-Hikmah. Kata "Al-Hikmah" menurut bahasa mengandung makna mengetahui keunggulan sesuatu melalui suatu pengetahuan, sempurna, bijaksana, dan sesuatu yang tergantung padanya akibat sesuatu yang terpuji. Kesesuaian antara kebenaran, filsafat, perkara yang benar dan lurus serta keadilan, pengetahuan dan lapang dada. Kata "AlHikmah" dengan bentuk jamaknya "Al-Hikam" bermakna: kebijaksanaan, ilmu dengan pengetahuan, filsafat, kenabian, keadilan, pepatah dan Al-Qur'an Al-Karim. Teori Al Hikmah adalah sebuah pedoman, penuntun dan pembimbing untuk memberi bantuan kepada individu yang sangat membutuhkan pertolongan dalam mendidik dan mengembangkan eksistensi dirinya hingga ia dapat menemukan jati diri dan citra dirinya serta dapat menyelesaikan atau mengatasi berbagai ujian hidup secara mandiri. Internalisasi nilai bimbingan konseling oleh pembimbing dengan teori ini dimaksudkan dengan pertolongan dari Allah. Sesungguhnya Allah SWT melimpahkan Al-Hikmah itu tidak hanya kepada para Nabi dan Rasul, akan tetapi Dia telah limpahkan juga kepada siapa saja yang dikehendaki-Nya, seperti firmanNya:

Artinya: Allah menganugerahkan Al Hikmah (kefahaman yang dalam tentang Al Quran dan As Sunnah) kepada siapa yang dikehendaki-Nya. Dan barangsiapa yang dianugerahi hikmah, ia benar-benar telah dianugerahi karunia yang banyak. Dan hanya orang-orang yang berakallah yang dapat mengambil pelajaran (dari firman Allah). (Q.S Al-Baqarah: 269)

b. Teori Al-Mau'izhoh Al-Hasanah yaitu teori bimbingan atau konseling dengan cara mengambil pelajaran-pelajaran dari perjalanan kehidupan para Nabi dan Rasul. Bagaimana Allah membimbing dan mengarahkan cara berfikir, cara berperasaan, cara berperilaku serta menanggulangi berbagai problem kehidupan. Bagaimana cara mereka membangun ketaatan dan ketaqwaan kepada-Nya. Yang dimaksud dengan Al-Mau'izhoh Al-Hasanah ialah pelajaran yang baik dalam pandangan Allah dan Rasul-Nya, yaitu dapat 
membantu klien untuk menyelesaikan atau menanggulangi problem yang sedang dihadapinya.

c. Teori Mujadalah Yang Baik. Yang dimaksud teori Mujadalah ialah teori konseling yang terjadi dimana seorang klien sedang dalam kebimbangan. Teori ini biasa digunakan ketika seorang klien ingin mencari suatu kebenaran yang dapat menyakinkan dirinya, yang selama ini ia memiliki problem kesulitan mengambil suatu keputusan dari dua hal atau lebih; sedangkan ia berasumsi bahwa kedua atau lebih itu lebih baik dan benar untuk dirinya. Padahal dalam pandangan konselor hal itu dapat membahayakan perkembangan jiwa, akal pikiran, emosional, dan lingkungannya. Prinsip-prinsip dari teori ini adalah sebagai berikut:

1. Harus adanya kesabaran yang tinggi dari konselor

2. Konselor harus menguasai akar permasalahan dan terapinya dengan baik.

3. Saling menghormati dan menghargai.

4. Bukan bertujuan menjatuhkan atau mengalahkan klien, tetapi membimbing klien dalam mencari kebenaran.

5. Rasa persaudaraan dan penuh kasih sayang.

6. Tutur kata dan bahasa yang mudah dipahami dan halus.

7. Tidak menyinggung perasaan klien.

8. Mengemukakan dalil-dalil Al-Qur'an dan As-Sunnah dengan tepat dan jelas.

9. Ketauladanan yang sejati.

Adapun lima cara yang dilakukan dalam komunikasi konseling menurut Richard Nelson dan Jones (2009) pada klien diantaranya dengan menggunakan:

1. Komunikasi Verbal

Komunikasi verbal bisa disebut dengan komunikasi dengan menggunakan percakapan, adapun hal yang diperhatikan dalam komunikasi vokal ini:

a. Bahasa. Bahasa merupakan elemen yang digunakan dalam penyampaian pesan. Penyampaian bahasa secara formal dan informl menjadi pemilihan dalam penyampaian pesan.

b. Isi. Isi yang dimaksud adalah bidang topik atau permasalahan yang akan dijadikan dalam topik pembahasan antara konselor dan konseli.

c. Banyaknya pembicaraan (Shyness). Kesempatan untuk menyampaikan pesan ketika mendapatkan giliran untuk berbicara. Kapasitas berbicara konselor harus disesuaikan dengan kebutuhan akan informasi yang disampaikan dalam kapasitas mendalami permasalahan klien.

d. Ownership of speech. Dalam hal ini, konselor tidak boleh melakukan penghakiman secara sepihak kepada klien agar, klien tidak merasa tersudutkan dalam menyelesaikan masalah.

2. Komunikasi Vokal

Pesan - pesan vokal saat dilakukan konseling menjadi pengaruh dalam penyampaian pesan. Penyampaian pesan dengan volume tentang apa yang sedang konseli rasakan, secara emosional seberapa respon klien terhadap konselor. Adapun lima dimensi dalam vokal ini diantaranya: 
a. Volume. Volume terkait dengan rendah tingginya suara dalam menyampaikan pesan kepada konseli. Beberapa klien membiarkan suaranya menipis diakhir kalimat. Sebagian saat menyampaikan pesan kepada klien, konselor perlu menyampaikan pesan dengan suara yang tegas, bilamana terdapat penguatan terhadap klien

b. Artikulasi. Artikulasi mengacu pada kejelasan/kejernihan suara saat menyampaikan pesan dalam konseling.

c. Pitch. Pitch mengacu pada ketinggian atau kedalaman suara anda.

d. Rate. Kecepatan dalam berbicara, diukur dalam jumlah kata per menit yang disampaikan. Kecepatan bicara ini juga bukan hanya dipengaruhi seberapa cepat frekuensi yang diucapkan, tetapi juga durasi penyampaian. Jika berbicara sangat cepat, konselor mungkin akan terlihat sangat cemas dan klien akan kesulitan memahami. Di pihak lain, bicara lamban akan terlihat membosankan bagi klien. Akan tetapi, jika berhenti dan diam pada saat yang tepat adalah merupakan aspek yang sangat penting dari kecepatan bicara ini.

3. Komunikasi tubuh

Baik pada saat berbicara maupun mendengarkan, konselor berusaha mengungkapkan diri melalui komunikasi dengan tubuh yang dilakukan. Bentuk komunikasi tubuh ini diantaranya sebagai berikut:

a. Ekspresi wajah. Ekspresi wajah menjadi dasar untuk mengirim pesan tubuh. Ekman, Priesen dan Ellsworth (1972) dalam Jones menyebutkan bahwa ada tujuh ekspresi wajah utama untuk emosi: happiness, interest, surprise, fear, sadness, anger dan disgust atau contempt. Mulut dan alis saat menyampaikan pesan dapat terlihat dan menyimpan banyak informasi, misalnya "down in the mounth"(= gundah gulana) dan raised eyebrows" (= ragu-ragu)

b. Gaze. Gaze adalah memandang orang lain di daerah wajahnya, yakni cara untuk memperlihatkan ketertarikan dan juga cara untuk mengumpulkan informasi fasial. Gaze berguna untuk mengkoordinasikan pembicaraan. Sebagai contoh, pembicara memandang tepat sebelum akhir ucapan untuk mengumpulkan umpan balik tentang reaksi pendengarnya.

c. Kontak mata. Kontak mata merupakan cara yang lebih langsung dibandingkan dengan gaze dalam mengirimkan pesan, apakah pesan ketertarikan, kemarahan atau ketertarikan seksual.

d. Gestures. Gestur adalah gerakan fisik yang dapat membingkai atau mengilustrasikan kata-kata yang datang sebelum, selama atau setelah diucapkan. Salah satu contoh penggunaan gestur untuk memperlihatkan sebuah emosi adalah mengepalkan tinju untuk menunjukkan agresi.

e. Postures. Postur klien dalam melakukan konseling ini menunjukkan pesan dalam konseling yang dilakukan. Memutar tubuh konselor ke arah klien lebih membesarkan hati, dibandingkan memalingkan tubuh.

f. Kedekatan fisik. Derajat kedekatan klien dan konselor, menunjukkan adanya rasa nyaman dalam melaksanakan konseling. 
g. Pakaian. Pakaian yang tidak sesuai dengan apa yang digunakan akan mempengaruhi seberapa besar posisi pekerjaan, posisi sosial seorang konselor dalam melaksanakan konseling dalam melayani klien.

h. Cara berdandan. Cara berdandan yang baik, menunjukkan performa konselor dalam merawat diri mereka. (Nelson-Jones, 2012)

Sering kali dalam konseling, klien merasakan adanya kepuasan dalam pelaksanaan konseling yang dilakukan diantara konselor dan klien. Hubungan yang baik antara konselor dan klien, dapat meningkatkan efektifitas pelaksanaan konseling dalam segala sisi.

\section{Pelaksanaan Konseling di Perguruan Tinggi}

Pemberian layanan konseling mahasiswa pada perguruan tinggi dilakukan melalui kegiatan perwalian oleh dosen wali studi. Adapun cara yang dilakukan dalam dua cara yaitu dengan tatap muka dan online. Adapun penjelasan sebagai berikut:

a. Tatap muka

Pelaksanaan tatap muka terhadap mahasiswa dalam rangka konseling dan identifikasi permasalahan individu secara langsung. Kegiatan konseling ini biasanya dilakukan secara terjadwal pada tiap angkatan, sehingga identifikasi permasalahan tiap tahap angkatan bisa diselesaikan dengan penangan yang tepat. Dalam tatap muka yang dilakukan, konten konseling ini bisa berupa penyelesaian permasalahan berupa:

1) Permasalahan Akademik yaitu berkaitan dengan permasalahan motivasi belajar, perlakukan pembelajaran, hafalan ayat Al-Qur'an, hafalan BTQ hingga peningkatan kemampuan akademik.

2) Permasalahan Pribadi, yaitu berkaitan dengan permasalahan sosialisasi, komunikasi dosen, peningkatan percaya diri dan peningkatan kemampuan non akademik.

3) Permasalahan sosial, yaitu berkaitan dengan organisasi, sosialisasi pada komunitas (Nihayah, 2018).

Konseling yang dilakukan oleh dosen wali dilakukan dengan cara tatap muka diimplementasikan kedalam bentuk komunikasi konseling dengan memperlihatkan hasil sebagai berikut:

1. Komunikasi Verbal

Komunikasi yang dilakukan mahasiswa menggunakan bahasa daerah mereka dengan menunjukkan adanya rasa hormat kepada dosen dengan menggunakan bahasa jawa krama inggil, dengan menunjukkan dosen sebagai strata yang lebih tinggi dari mahasiswa dalam akademik. Bahasa dari dosen sebagai pembimbing akademik, melakukan tutur kata yang lembut dan bisa dipahami, dengan menggunakan bahasa krama alus atau juga menggunakan bahasa Indonesia baku bagi mahasiswa yang berasal dari luar Jawa. (Nihayah, 2018).

Saat pelaksanaan konseling akademik, konselor bertanya terkait dengan studi hasil tugas akhir yang dilakukan mahasiswa juga sudah fokus dalam topik pembicaraan dengan penyampaian jawaban yang sesuai dengan pertanyaan yang dijawab oleh dosen wali. Pertanyaan seputar tugas akhir ini, termasuk terkait prospek hasil dari tugas akhir, kesulitan yang dialami, faktor internal mahasiswa maupun faktor eksternal mahasiswa dalam 
melaksanakan tugas akhir skripsi. Jawaban yang sesuai juga di sinkronkan dengan dosen pembimbing sebagai dasar informasi penyelesaian tugas akhir mahasiswa.

Pada perwalian terjadwal, mahasiswa terbatas oleh waktu dalam konsultasi yang dilakukan. Akan tetapi, jika memang terdapat kesulitan di luar waktu perwalian mahasiswa bisa melakukan konseling secara langsung dengan dosen wali studi dengan menyesuaikan waktu dosen wali.

Ketika sampai pada titik diskusi konsultasi dosen dan mahasiswa, dosen wali melakukan penghakiman secara sepihak pada mahasiswa yang jarang melakukan komunikasi dengan dosen wali. Harapan untuk melakukan konseling preventif dalam penyelesaian tugas akhir tidak bisa dilakukan secara maksimal. Komunikasi dengan verbal dan hanya sepihak tidak menjadikan konselor cukup informasi klien.

\section{Komunikasi Vokal}

Penyampaian konseling dengan rendah dan tinggi disesuaikan dengan kondisi mahasiswa. Perwalian yang terjadwal biasanya dilakukan dengan metode konseling kelompok, secara bersamaan dengan mahasiswa dengan disesuaikan dengan tahun masuk dengan permasalahan yang hampir sama.

Penyampaian pesan konseling sudah dilakukan dengan jelas oleh dosen wali, misalnya saat dilakukan konsultasi mahasiswa terkait persiapan TOEFL dan IMKA dosen wali menyampaikan dengan tegas dan jelas persyaratan yang dibutuhkan serta kesiapan mahasiswa dalam melakukan tes TOEFL dan IMKA sebelum ujian munaqosah. (Nihayah, 2018)

Ketinggian dan kedalaman suara dalam melakukan konseling disesuaikan dengan penguatan yang diberikan dalam melakukan konseling sebagai motivasi dalam penyelesaian tugas akhir. Penguatan nada ini sebagai bentuk penekanan terhadap pesan yang disampaikan dan dirasa penting.

Penyampaian pesan dalam konseling oleh dosen dalam penyelesaian tugas akhir sudah dilakukan dengan kecepatan berbicara yang disesuaikan dengan pemahaman mahasiswa. Apabila ada kata-kata yang kurang dipahami, maka dosen akan mengulang kembali, sehingga penyampaian informasi bisa secara keseluruhan ditangkap.

\section{Komunikasi tubuh}

Ekspresi wajah dalam melaksanakan konseling ini, menunjukkan performa konselor. Ekspresi dosen saat melakukan konseling dengan disesuaikan dengan apa yang terjadi dan dilakukan oleh klien. Akan tetapi, dosen berusaha menyembunyikan ekspresi tidak suka kepada mahasiswa yang melakukan penyimpangan pembelajaran dan bermasalah dengan akademik. Dengan ekspresi yang agak ditahan, dosen wali berusaha menemukan informasi terkait kesulitan belajar dari mahasiswa sehingga tidak bisa menyelesaikan tugas akhir dengan tepat waktu. Bukan hanya itu, gaze terhadap mahasiswa yang bermasalah dengan mencari akar permasalahan yang diamati menjadi ketertarikan untuk mengumpulkan informasi dari luar diri mahasiswa.

Pada saat melakukan kontak mata dengan lawan jenis, dosen tidak terlalu melakukan kontak mata secara langsung sebagai bentuk penghormatan dan etika kepada lawan jenis. Ada perasaan tidak enak ketika melakukan kontak terlalu lama oleh karena itu kontak mata disesuaikan dengan kebutuhan. Berbeda dengan yang sejenis, dosen selaku konselor cenderung untuk melakukan kontak mata secara langsung sebagai bentuk pendalaman 
informasi kepada klien sehingga informasi bisa tergali. Dosen mengamati tatapan mata klien, ketika mereka membuang tatapan mata mereka. Ada kemungkinan klien melakukan kebohongan saat kontak mata dilakukan dengan melihat ciri yang dilakukan dalam pelaksanaan konseling.

Konsultasi yang dilakukan kepada mahasiswa yang mempunyai masalah akademik cenderung bersifat langsung. Sehingga saat bertatap muka, gestur dari mahasiswa terlihat bermain tangan dan beberapa diantaranya memainkan pulpen saat dilakukan konsultasi. Mahasiswa dengan kecenderungan seperti ini biasanya mencari alasan tertentu saat dilakukan tanya jawab terhadap dosen.

Sikap saat bertatap muka dengan klien disesuaikan dengan kondisi ruangan yang ada. Kebanyakan dosen melakukan konsultasi dengan menghadap tubuh mahasiswa dengan cara berhadap-hadapan dengan dibatasi meja kerja dosen saat dilakukan konsultasi. Jarak tubuh saat konsultasi dekat dan dibatasi meja ini juga menunjukkan kedekatan saat melakukan komunikasi saat konsultasi dilakukan. Hal ini bertujuan apabila saat menyampaikan sesuatu yang bersifat rahasia kepada dosen, bisa didengar dengan jelas tanpa mengurangi asas kerahasiaan saat dilakukan konsultasi.

Cara berdandan dosen sebagai akademisi, memperlihatkan performa mereka saat melakukan pembelajaran. Hal ini juga dilakukan saat dilakukan konseling kepada mahasiswa. Adanya penghormatan kepada dosen sebagai konselor serta orang tua pengganti mereka saat di perguruan tinggi menunjukkan performa dosen untuk selalu berpakaian rapi dan sopan saat berada dikampus (Nihayah, 2018).

b. Online

Konseling secara online biasa dilakukan oleh dosen melalui media sosial facebook, Instagram dan WhatsApp. Dosen yang terbiasa melakukan komunikasi melalui media sosial lebih mudah mengidentifikasi aktivitas mahasiswa dengan berbagai aktivitas yang dilakukan. Selain itu pada pelaksanaan konseling melalui media online ini berbasis pada database perwalian yang diatur oleh pihak PTIPD (Pusat Teknologi Pangkalan Data) UIN Walisongo Semarang dalam support system pelaksanaaan perwalian secara online. Data ini juga berkaitan dengan hasil perwalian yang bisa diinput melalui situs http://akademik.walisongo.ac.id. Perwalian dilakukan secara terjadwal dilakukan sesuai dengan kalender akademik yang ada pada masing-masing Fakultas agar tidak terjadi overload. Hasil perwalian yang diinput bisa dilakukan validasi oleh mahasiswa sebagai bukti perwalian online dosen dan bentuk monitoring.

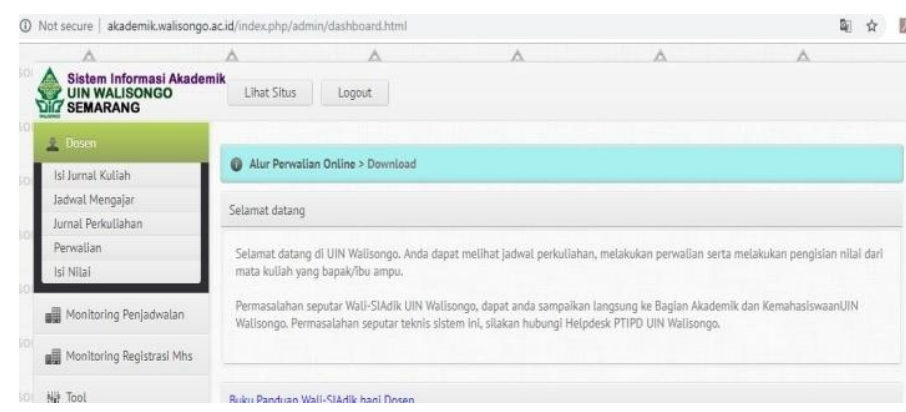

Gambar 1.

Menu akademik.walisongo.ac.id pada tampilan dosen 


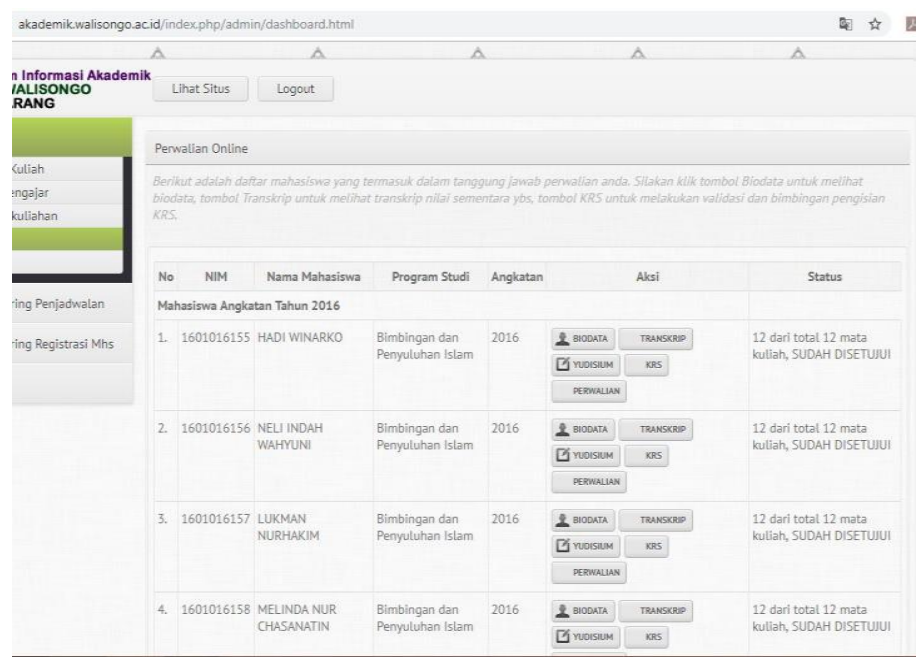

Gambar 2.

Menu perwalian dengan tampilan daftar mahasiswa dibawah perwalian

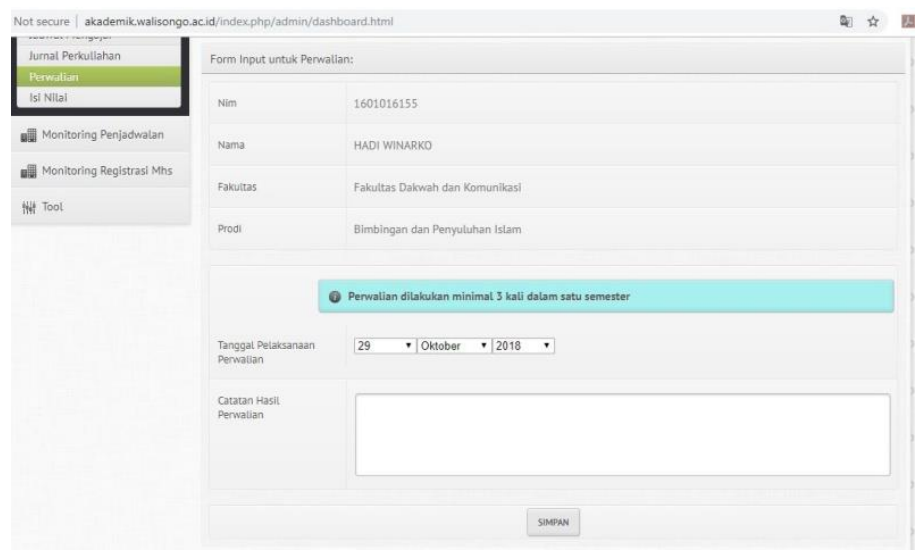

Gambar 3.

Tampilan isian perwalian yang diisi oleh dosen wali studi

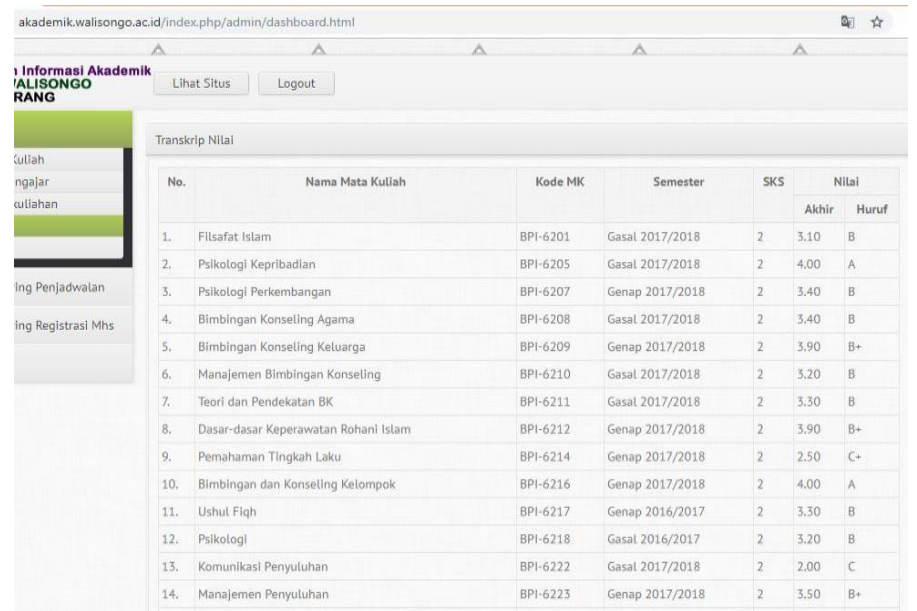

Gambar 4.

Tampilan monitoring transkip nilai mahasiswa 


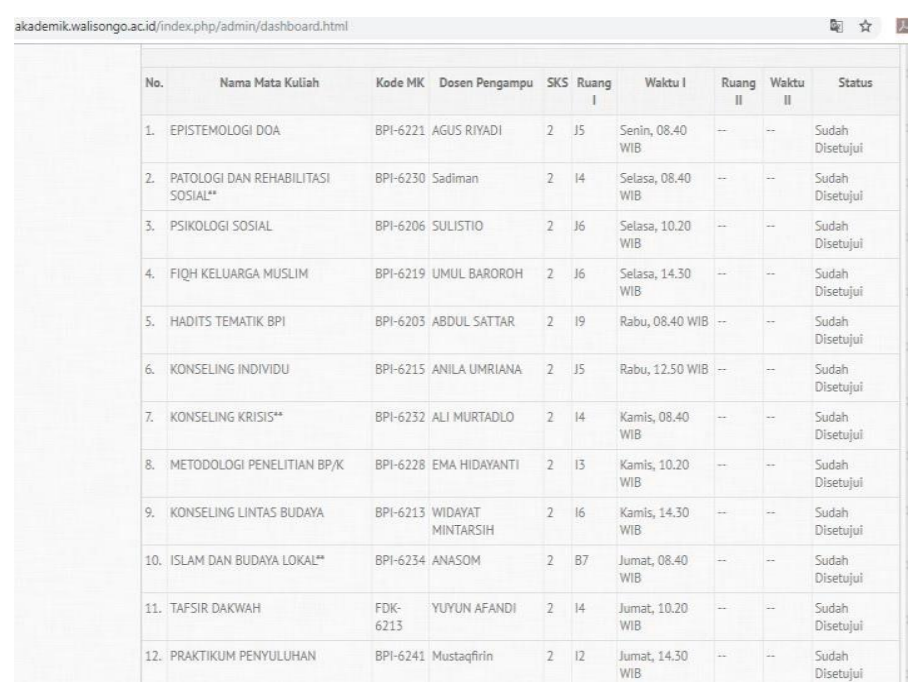

Gambar 5.

Tampilan Kartu Rencana Studi sebelum mahasiswa mengambil mata kuliah

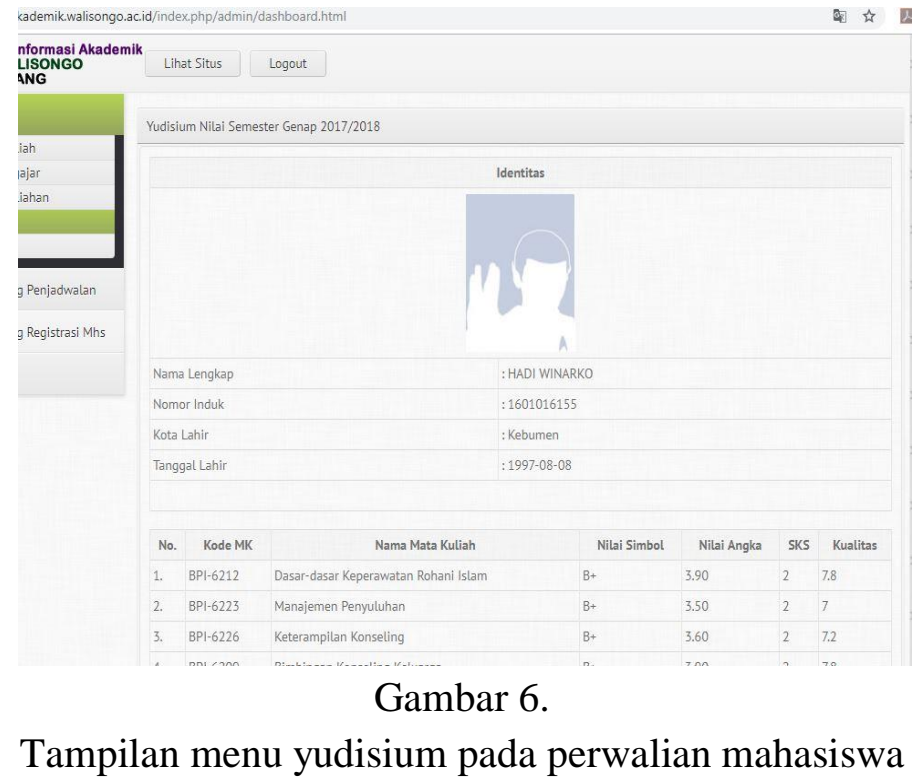

Setiap mahasiswa dibimbing oleh dosen wali studi yang ditunjuk oleh dekan. Adapun tugas-tugas dari wali studi secara umum sebagai berikut:

a. Mengarahkan mahasiswa dalam memilih mata kuliah yang diambil pada permulaan semester.

b. Memberikan pertimbangan kepada mahasiswa dalam hal jumlah SKS yang akan diambil.

c. Membantu kelancaran administrasi akademik seperti pengesahan berlakunya Formulir Rencana Studi (FRS) dan Kartu Studi Tetap (KST).

d. Mendorong dan menanamkan kesadaran pada mahasiswa untuk belajar teratur, berkelanjutan dan berkesinambungan, disiplin dan berakhlak luhur.

e. Memantau perkembangan studi mahasiswa yang dibimbing dengan jalan:

1) Mengadakan pertemuan periodik untuk memecahkan kesulitan mahasiswa.

2) Meminta laporan periodik tentang kemajuan belajar mahasiswa. 
3) Menginventarisasi kegiatan lain yang dianggap perlu

f. Memberikan rekomendasi dan keterangan-keterangan lain tentang mahasiswa yang dibimbing kepada pihak-pihak lain.

g. Memberikan peringatan lisan atau tertulis kepada mahasiswa bimbingannya yang berprestasi kurang.

h. Membantu pimpinan fakultas untuk membina mahasiswa yang dibimbingnya dalam kehidupan kampus sesuai dengan tata tertib mahasiswa.

i. Memberikan laporan tertulis kepada dekan mengenai tugasnya, setidak-tidaknya setiap akhir semester

j. Mengidentifikasi mahasiswa yang diperkirakan bermasalah kemudian melakukan:

1) Pegangan khusus sesuai dengan kemampuan dosen wali.

2) Memberikan rekomendasi kaprodi/ketua jurusan/wakil dekan I untuk bermasalah administratif.

Adapun masa tugas dosen wali studi penjelasannya sebagai berikut:

a. Masa tugas dosen wali studi sama dengan masa studi mahasiswa yang bersangkutan.

b. Dekan memberikan peringatan kepada dosen wali studi yang tidak menjalankan tugasnya dengan baik.

c. Dekan dapat meninjau kembali penunjukan dosen wali studi apabila ternyata terdapat ketidakserasian antara dosen wali studi dengan mahasiswa yang bersangkutan.

Adapun syarat dosen wali studi antara lain:

1) Dosen UIN walisongo yang mendapatkan surat tugas dari dekan.

2) Telah mengikuti persiapan dan pembekalan sebagai dosen wali studi.

3) Empati, dapat dipercaya, bijaksana, memiliki komitmen terhadap tugas dosen wali (Semarang, 2017)

Sebagaimana dalam PP. 30 tahun 1990, tentang fungsi Perguruan Tinggi dan pada PP 60 tahun 1999 Bab II pasal 2 tujuan pendidikan tinggi. Atas dasar UU dan PP di atas, maka seorang dosen sebagai salah satu anggota sivitas akademika Perguruan Tinggi memiliki peran dan fungsi yang sangat strategis. Adapun peran dan fungsi tersebut yaitu:

a.) Dosen adalah sebagai organisator, dalam arti dosen harus mampu mengorganisir kegiatan belajar mahasiswa sehingga mencapai keberhasilan belajar yang optimal.

b.) Dosen sebagai fasilitator dimaknai peran dosen harus mampu memberikan kebebasan bagi mahasiswa dalam mengembangkan potensi yang dimilikinya, serta berusaha membina kemandirian mahasiswa.

c.) Dosen sebagai inovator dimaknai dengan adanya pengetahuan yang disampaikan kepada mahasiswa harus selalu Up To Date, dalam arti mampu menyerap nilai-nilai budaya yang serba canggih dan selalu mengkaji pengalaman. Dalam hal ini, dosen dituntut untuk selalu mengkaji ilmu pengetahuan dan teknologi, bersikap demokratis, memberikan kemungkinan kepada mahasiswa untuk berkreasi dan dapat menemukan konsep dan prinsip sendiri serta membantu mahasiswa dalam mencari sumber dan kegiatan belajar. 
d.) Dosen sebagai penemu artinya, disamping tugas pokoknya mengajar, dosen juga harus melaksanakan penelitian baik yang berhubungan dengan kegiatan belajar mengajar maupun yang sesuai dengan bidang keahliannya. Dengan mewujudkan penelitian ini diharapkan dosen mampu menghasilkan temuan-temuan baru yang konstruktif untuk selanjutnya dapat disumbangkan kepada penentu kebijakan melalui lembaganya masingmasing demi kemajuan ilmu pengetahuan dan teknologi.

e.) Dosen sebagai teladan artinya yang memberi contoh bukan hanya cara berpikir saja tetapi dalam hal bersikap, bertindak serta berprilaku.

f.) Dosen sebagai evaluator artinya: harus mengerti, memahami dan menguasai hakekat evaluasi. Evaluasi di sini dapat dipergunakan secara tidak terbatas, meliputi beberapa aspek kehidupan, tetapi juga dapat dipergunakan untuk melihat satu aspek saja, tetapi juga prestasinya. Yang menjadi perhatian adalah adanya evaluasi terhadap hasil belajar itu menunjukkan pula bagaimana prestasi mengajar dosen

g.) Dosen adalah sebagai pemandu artinya, menunjukkan jalan bagi perjalanan belajar para mahasiswanya.

h.) Dosen sebagai pencipta, artinya dosen harus mampu menciptakan situasi dan kondisi belajar yang kondusif, sehingga proses belajar mengajar berjalan dengan baik.

i.) Dosen sebagai pengabdi dan pelayan bagi masyarakat, artinya dosen selain mengajar juga melakukan pengabdian kepada masyarakat dengan ilmu pengatahuan serta pengalaman dan segala potensi yang dimiliki sebgai sumbangsihnya untuk kemajuan masyarakat.

j.) Dosen sebagai konselor, artinya dosen harus mampu membantu mahasiswanya dalam memecahkan kesulitan baik dalam kegiatan belajar maupun yang lainnya. (UU Guru dan Dosen No. 14, 2005)

\section{Analisis Komunikasi Konseling}

Berkaitan dengan peran dosen sebagai konselor, dosen bukan hanya membantu dalam rangka kegiatan belajar maupun memecahkan kesulitan diluar pembelajarannya. Dosen mempunyai tugas ganda diluar wujud Tri Dharma perguruan tinggi. Adapun analisis komunikasi konseling ini dilaksanakan dengan cara:

a. Komunikasi verbal

Komunikasi konseling secara verbal telah dilakukan dosen sebagai konselor dalam perguruan tinggi dalam rangka pembelajaran di perguruan tinggi. Komunikasi verbal ini dilakukan dengan bahasa lisan dengan tatapan muka. Bahasa lisan yang dilakukan saat konsultasi ini hanya bisa menunjukkan tendensi kata-kata saat mengisi perwalian online. Lebih dari itu, konsultasi yang bersifat verbal menunjukkan beberapa komunikasi dalam konseling diantaranya:

1. Bahasa: Pada penggunaan bahasa ini, konseling memang cenderung bersifat kaku akan tetapi, budaya dalam komunikasi konseling ini menjadikan kenyamanan 
mahasiswa dalam berkonsultasi, karena menganggap konselor dalam hal ini dosen menjadi sosok pendengar layaknya orang tua mereka saat dilakukan konseling.

2. Fokus dan topik pembicaraan disesuaikan dengan konsultasi yang dilakukan oleh konselor saat melakukan konseling.

3. Banyaknya pembicaraan yang dilakukan disesuaikan dengan durasi waktu yang disediakan oleh dosen saat dilakukan konseling kelompok. Karena saat perwalian terjadwal dilakukan batasan waktu terjadwal oleh akademik saat konsultasi. Diluar dari jadwal, klien boleh melakukan konsultasi sesuai dengan waktu yang disediakan oleh dosen.

4. Konselor sebagai sosok sentral dalam pelaksananaan konsultasi mempunyai peran dalam mengarahkan klien dalam penyelesaian masalah. Komunikasi menjadi kunci utama dalam konseling sehingga perlu adanya objektivitas dalam pelaksanaan konseling, sehingga tidak terjadi penghakiman sepihak seperti yang dilakukan, sayangnya tidak semua mahasiswa melakukan komunikasi yang baik dengan dosen sebagai sentra konseling.

b. Komunikasi vokal

Komunikasi vokal ini menunjukkan adanya pengaruh penyampaian saat konseling dilakukan sehingga mahasiswa bisa merasakan respon dan feedback yang diberikan oleh konselor saat dilakukan konsultasi.adapun bentuk respon yang ada pada komunikasi vokal ini diantaranya:

1. Volume yang jelas saat dilakukan konseling. Penjelasan yang tinggi akan menunjukkan penekanan dalam kalimat dan penyampaian pesan. Kondisi ini disesuaikan dengan kondisi dan permasalahan mahasiswa saat dilakukan konseling.

2. Artikulasi dosen yang jelas menunjukkan adanya penjelasan yang berulang dan memahamkan mahasiswa dalam melakukan konseling, sehingga pesan dengan tepat disampaian sebagai bentuk respon terhadap permasalahan yang dialami oleh klien.

3. Ketinggian dan kedalaman suara disesuaikan konsultasi yang dilakukan pada mahasiswa. Kondisi psikis mahasiswa dengan problem yang berat cenderung menunjukkan suara yang dalamdan konselor menyesuaikan kedalaman suara dengan konsultasi yang dilakukan.

c. Komunikasi tubuh

Komunikasi konseling dengan tubuh ini menunjukkan adanya kedekatan antara mahasiswa dengan dosen sebagai dasar informasi dalam melakukan konseling. Komunikasi tubuh dalam konseling ini memperlihatkan bentuk komunikasi sebagai berikut:

1) Ekspresi wajah disesuaikan dengan kondisi dalam konseling. konselor tidak menunjukan paras tidak suka akan tetapi sebagai bentuk objektifitas dalam konselor agar konselor dapat mendapatkan informasi yang cukup dalam konseling.

2) Kontak mata yang dilakukan bukan bermaksud memilih konseli akan tetapi bentuk penghormatan kepada konseli. Kontak mata menunjukkan adanya ke 
dalam informasi yang didapatkan oleh konselor dalam menangani klien dengan berkata bohong atau tidak saat dilakukan konseling. Kedekatan fisik ini dilihat dengan adanya cara duduk yang berhadapan bermaksud untuk membuka pembicaraan dan menunjukkan adanya kedekatan antara konselor dan konseli. Kedekatan ini juga dibatasi oleh meja konsultasi, jadi perasaan tidak nyaman saat berbicara tetap mengutamakan asas kerahasiaan

Cara berpakaian konselor sudah menunjukkan adanya kepercayaan diri konselor dalam menerima klien. Pada saat dilakukan konseling, konselor menunjukkan performa sebagai pribadi yang disiplin dan rapi saat berpakaian sehingga klien menjadi nyaman saat konseling dilakukan.

\section{Simpulan}

Pelaksanaan komunikasi konseling di UIN Walisongo Semarang mengacu pada keterampilan konseling yang dilakukan konselor. Konselor berusaha objektif dan melakukan fungsi bimbingan konseling sesuai dengan kebutuhan klien. Konselor juga berusaha menjadi pendengar yang baik layaknya orang tua klien dalam memahami setiap permasalahan yang dihadapi oleh klien. Adapun bentuk komunikasi konseling yang dilakukan berbentuk verbal, vokal dan komunikasi tubuh.

1. Komunikasi verbal dalam konseling yang terjadi di UIN Walisongo Semarang diimplementasikan dalam bentuk bahasa penyampaian, artikulasi yang jelas, dan ownership of speech. Komunikasi konseling yang bersifat preventif pada klien, masih belum dilaksanakan maksimal karena kurangnya informasi yang didapatkan dari klien akibat kurangnya komunikasi intensif dengan klien. Ini menyebabkan konselor ownership of speech dalam konseling yang dilakukan.

2. Komunikasi vokal dilakukan dengan volume yang jelas saat berkomunikasi, artikulasi yang jelas saat menyampaikan pesan sehingga pesan yang tidak dipahami bisa diulang kembali serta ketinggian dan kedalaman suara yang jelas saat menghadapi klien disesuaikan dengan kondisi klien. Penguatan vokal pada saat komunikasi menjadi ciri motivasi saat dilakukan konseling terutama pada mahasiswa yang menyelesaikan tugas akhir.

3. Komunikasi tubuh, melalui kontak mata, gestur, cara berpakaian yang sesuai, kedekatan fisik dan tatapan saat melakukan konseling.

\section{Referensi}

(n.d.). In U. g. 2005.

Cangara, H. (2010). Pengantar Ilmu Komunikasi. Jakarta: PT. Raja Grafindo.

Effendi, D. K. (2016). Proses dan Ketrampilan Konseling . Bandung: Pustaka Pelajar.

Latipun. (2011). Psikologi Konseling. Malang: UMM Press.

Moekijat. (2011). Teori Komunikasi. In Bandung. Bandung: Mandar Maju. 
Mulyana, D. (2013). Ilmu Komunikasi Suatu Pengantar. Bandung: PT. Remaja Rosdakarya.

Nihayah, U. (2018). Efektifitas layanan bimbingan konseling dalam penyelesaian tugas akhir skripsi mahasiswa(studi pada dosen wali studi di uin walisongo semarang). Semarang: LP2M UIN Walisongo.

Effendy, O.U. (2008). Dinamika Komunikasi. Bandung: PT. Remaja. Rosdakarya.

Nelson-Jones, R. (2012). Pengantar Ketrampilan Konseling. Yogyakarta: Pustaka Pelajar.

Salman, Candrasari \& Rewindinar. (2016). Strategi komunikasi dalam Meningkatkan Kualitas Hidup Remaja. In Jurnal Bisnis dan Komunikasi, Kalbi Socio, Volume 2, No 3 Agustus 2016. Institut Bisnis Kalbis.

Saputro, H. A. (2017). Pengaruh Komunikasi Efektif untuk Meningkatkan Hasil Belajar Mahasiswa. In Jurnal Ilmiah Kependidikan, Vol IX, No 1(September 2017) . Jakarta: Universitas Indraprasta PGRI Jakarta.

Semarang, U. W. (2017). Buku Panduan Akademik Sarjana(S1) dan Diploma(DIII) UIN Walisongo Semarang. Semarang: UIN Walisongo.

Sukardi, D. K. (2008). Jakarta: Rieneka Cipta.

Sukitman, T. (2015). Bimbingan dan Konseling. Yogyakarta: Diva Press.

Vardiansyah, D. (2008). Filsafat Ilmu Komunikasi Suatu Pengantar, Cet. II. Jakarta: PT Indeks.

Walgito, B. (2010). Pengantar Psikolog Umum. Yogyakarta: CV Andi Offset 